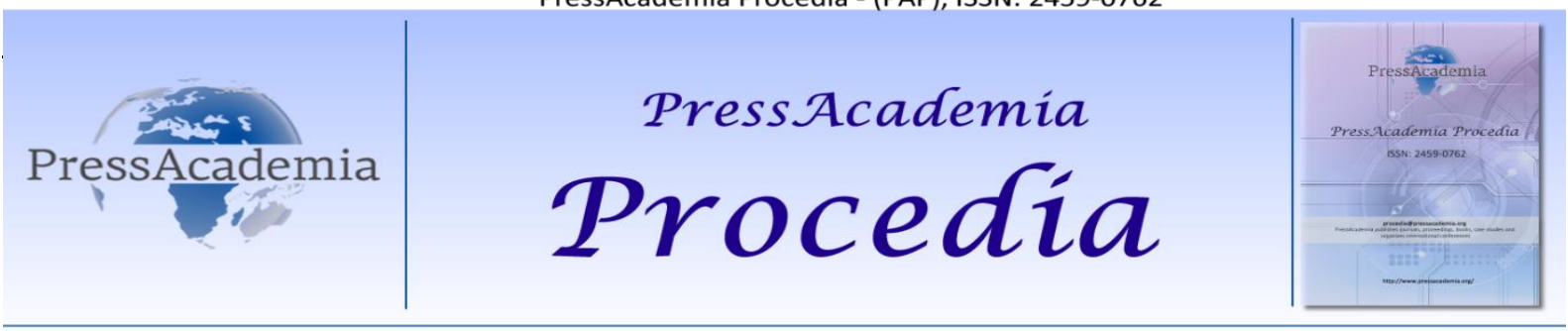

Global Business Research Congress (GBRC), May 24-25, 2017, Istanbul, Turkey.

\title{
EVALUATION OF SMES IN ESKISEHIR WITHIN THE CONTEXT OF INDUSTRY 4.0
}

\section{DOI: 10.17261/Pressacademia.2017.672 \\ PAP-GBRC-V.3-2017(99)-p.900-908}

Celal Hakan Kagnicioglu ${ }^{1}$, Emircan Ozdemir ${ }^{2}$

${ }^{1}$ Anadolu University, Eskisehir, Turkey. chkagnic@anadolu.edu.tr

${ }^{2}$ Anadolu University, Eskisehir, Turkey. emircanozdemir@anadolu.edu.tr

To cite this document

Kagnicioglu, C. H., and E. Ozdemir, (2017). Evaluation of SMEs In Eskisehir within the context of industry 4.0. PressAcademia Procedia (PAP), V.3, p.900-908.

Permemant link to this document: http://doi.org/10.17261/Pressacademia.2017.672

Copyright: Published by PressAcademia and limited licenced re-use rights only.

\begin{abstract}
It is important for businesses to keep up with the Industry 4.0 and to adapt their manufacturing systems to new technologies so that they can maintain their competitive edge in global markets. However, since these components are developing so fast, it is crucial for companies to be aware of Industry 4.0 for making on time transition to new technologies. Within the scope of the study, research evaluates the awareness of Industry 4.0, the Industry 4.0 applications and the Industry 4.0 perspective of SMEs in the manufacturing sector in Eskise hir. The components of Industry 4.0 are defined as robots, simulation, software integration, internet of things, cyber security, cloud systems, additive manufacturing, enriched reality, big data analysis, artificial intelligence, smart production and cyber physical systems. In the first part of the survey awareness of Industry 4.0, in the second part, Industry 4.0 components applied by the companies, in the last part, their perspective of Industry 4.0 are measured. While the awareness of SMEs in the manufacturing sector in Eskisehir is enhanced, Industry 4.0 technologies being used are inadequate. SMEs plan to adopt Industry 4.0 technologies in medium and long term. In this transition process, investment cost is the biggest problem for SMEs. Also, SMEs don't have adequate information about Industry 4.0. During cyber security, cloud systems and simulation components have higher rates; internet of things, cyber physical systems, enriched reality and artificial intelligence have lower rates. SMEs needs collaborations in order to adopt Industry 4.0 technologies. Also medium and long term Industry 4.0 strategies should be developed.
\end{abstract}

Keywords: Industry 4.0, fourth industrial revolution, SME, internet of things, smart manufacturing JEL Codes: L60, M11, 033

\section{ENDÜSTRI 4.0 BAĞLAMINDA ESKIŞEHIR İLINDEKI KOBI'LERIN DEĞERLENDIRILMESi}

\section{ÖZET}

İşletmelerin küresel piyasalardaki rekabet gücünü koruyabilmeleri için dördüncü sanayi devrimine ayak uydurmaları ve üretim sistemlerini yeni teknolojilere adapte etmeleri önem taşımaktadır. Ancak bu bileşenlerin gelişimi oldukça hızlı olduğundan dolayı işletmelerin Endüstri 4.0 konusunun farkında olmaları, üretim sistemlerinin yeni teknolojilere zamanında geçiş yapmaları açısından hayati önem taşımaktadır. Çalışma kapsamında Eskişehir ilinde imalat sektöründe yer alan KOBi'lerin Endüstri 4.0 uygulamaları hakkındaki farkındalıkları, hangi uygulamaları kullandıkları ve bakış açılarının değerlendirilmesi amaçlanmıştır. Araştırmada Endüstri 4.0'ın bileşenleri akıllı robotlar, simülasyon, yazılım entegrasyonu, nesnelerin interneti, siber güvenlik, bulut sistemleri, eklemeli üretim, zenginleştirilmiş gerçeklik, büyük veri analizi, yapay zeka, akıllı üretim ve siber fiziksel sistemler olarak belirlenmiştir. Araştırma kapsamında hazırlanan ankette ilk bölümde Endüstri 4.0 farkındalı̆̆ı, ikinci bölümde işletmelerin hangi bileşenleri uyguladıkları, son bölümde ise Endüstri 4.0’a karşı işletmelerin bakış açıları ölçülmektedir. Eskişehir ilinde imalat sektöründe yer alan KOBi'lerin Endüstri 4.0 farkındalığııın gelişmiş olmasına rağmen, kullanılan Endüstri 4.0 teknolojileri konusunda yetersiz kalındığı görülmektedir. İşletmeler orta ve uzun vadeli planda Endüstri 4.0 teknolojilerine geçiş planlanmaktadır. Bu geçiş sürecinde işletmeleri en fazla zorlayan unsurun yatııım maliyeti olduğu ortaya konmuştur. Ayrıca işletmelerin bilgi eksikliği de gözlemlenmiştir. Siber güvenlik, bulut ve simülasyon bileşenlerinin kullanım düzeyi yüksek iken, yapay zekâ, nesnelerin interneti, artırımış gerçeklik ve siber fiziksel sistemler geri kalınan bileşenlerdir. İ̧̧letmelerin Endüstri 4.0 teknolojilerini kullanmalarını 
sağlamaya yönelik paydaşların desteklerine ihtiyaç duyulmaktadır. Ayrıca orta ve uzun vadeli Endüstri 4.0 stratejilerinin geliştirilmesi konusu önem taşımaktadır.

Anahtar Kelimeler: Endüstri 4.0, dördüncü sanayi devrimi, KOBi, nesnelerin interneti, akıllı üretim

JEL Kodları: L60, M11, 033

\section{GíRiş}

Sanayi devriminden bu yana endüstriyel açıdan büyük değişimlere işaret eden üç ana aşama yer almaktadır. Her bir ana aşamada iş dünyasındaki paradigmalar köklü değişikliklere uğramıştır ve şirketlerin ve ülkelerin rekabet gücünü kapsamlı şekilde dönüşüme zorlamıştır. Belirtilen endüstriyel devrim aşamaları günümüzde Endüstri 1.0, Endüstri 2.0 ve Endüstri 3.0 şeklinde adlandırılmaktadır. Her bir endüstriyel devrim bir versiyon olarak ele alınmaktadır.

Sanayi devrimi; günümüz toplumsal, siyasal ve ekonomik ilişkilerinin başlangıç noktası olarak kabul edilebilen, tarihsel açıdan toplumlar için bir dönüm noktasıdır. Tarihsel süreci milattan önce ve sonra gibi ikiye ayırabildiğimiz gibi endüstriyel ilişkiler, toplumsal ilişkiler, siyasal ve ekonomik süreçler için de sanayi devrimi öncesi ve sonrası gibi bir ayrım pekâlâ mümkün olabilir (Görçün, 2016, s. 11).

Teknolojik ilerlemeler, sanayi devriminin başlangıcından bu yana, endüstriyel verimlilikte büyük artışa işaret eden üç ana aşamanın kat edilmesini mümkün kılmıştır. 18. yüzyıın sonlarında fabrikalarda buhar gücüyle çalışan makineler kullanılmaya başlanmış, 20. yüzyılın başında elektrik enerjisi ile seri üretim mümkün olmuş, 1970'lerden itibaren ise elektronik ve bilgi teknolojileri (BT) ile sanayide otomasyon yaygınlaşmıştır (TÜsiAD, 2016, s. 19).

20. yüzyılın son çeyreği ile birlikte bilişim ve iletişim teknolojilerinde hızlı bir gelişme yaşanmıştır. İnternet ile ilgili uygulamalar ve bunların kullanıc sayıları ile çeşitliliğinde adeta bir patlama yaşanmıştır. Aynı şekilde bu yapı içerisinde otomasyon, sensör, veri değişimi ve üretim teknolojilerinde geçmiş dönemlere göre önemli değişiklikler yaşanmıştır. Tüm bu gelişmeleri bir araya getirerek düşünsel anlamda birleştiren yaklaşım ise günümüzde Endüstri 4.0 olarak adlandırılmaktadır. Endüstri 4.0 en basit haliyle; bilişim, iletişim, internet, otomasyon, veri toplama ve yayma teknolojilerinin yeni üretim olanakları ile entegrasyonu anlamına gelmektedir (Banger, 2016, s. 75).

Tarihsel bağlamda 1970'ten günümüze kadar olan dönemde etkisini sürdürmekte olan Endüstri 3.0 ya da üçüncü sanayi devrimi günümüzde yerini Endüstri 4.0'a ya da diğer bir deyişle dördüncü sanayi devrimine bırakmıştır. Bu kapsam ilk olarak 2011 yılında Hannover Fuarı'nda (Almanya) kullanılmıştır. Uzmanların burada kendilerine sordukları soru esasında çok basitti: "Hemen hemen tüm bilgisayarların birbirine bağlı olduğu günümüzde, üretim sırasında ve sonrasında özellikle fabrikalar gibi büyük üretim tesislerindeki makineler ile diğer üretim araç ve gereçlerinin hem birbirleriyle hem de ürettikleri ürünler ile bağlantıda olması neden mümkün olmasın?". Tüm bunların yanı sıra bu ürünler, tıpkı üretildikleri makineler gibi sürekli internete bağlı olacak (dolayısıyla konumları ve durumları her an kolaylıkla belirlenebilecek), sensörleri sayesinde bulundukları çevreyi inceleyip gerektiğinde yine kendi yetenekleri ölçüsünde fiziksel tepki verebilecek ve bunu yaparken de tüm dünya genelinde internete bağı diğer cihazlarla gerçek zamanlı olarak bilgi alışverişinde bulunabilecekler (Ege, 2014, s. 27). Endüstriyel devrimlerin tarih sahnesinde kronolojik olarak gösterimi Şekil 1'de verilmiştir.

\section{Şekil 1: Endüstriyel Devrimlerin Kronolojik Gösterimi}

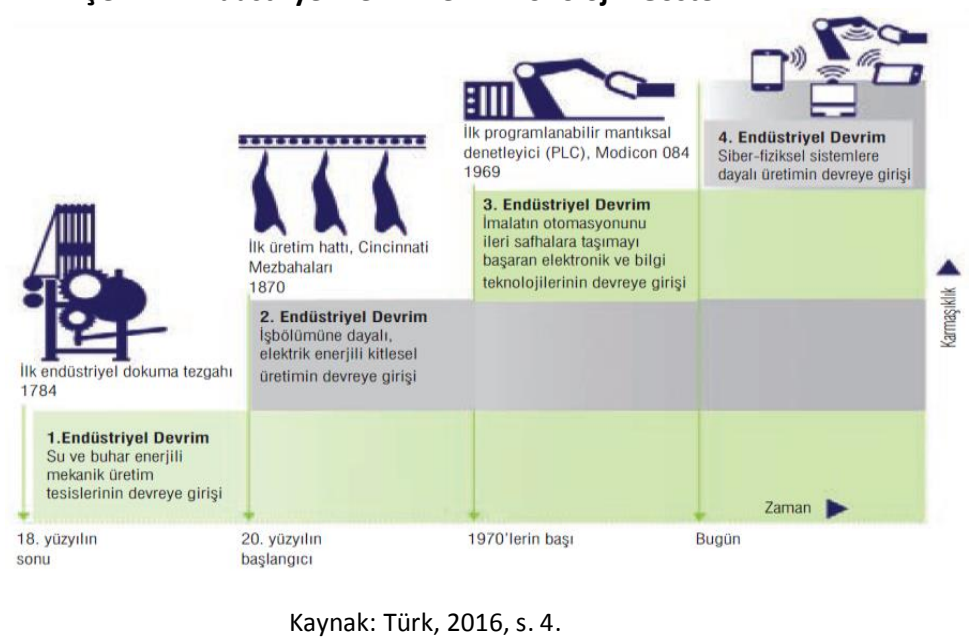


Endüstriyel devrimsel tarihsel gelişimi en kısa ve anlaşlır haliyle Şekil 1.1'de özetlenmektedir. Sanayi devriminin özünde yatan ve buhar gücüyle çalışan makinelerin üretim teknolojilerini şekillendiren teknolojik gelişmeler ışığında Endüstri 1.0 olarak adlandırılan dönem başlamaktadır. Daha sonra kitlesel üretimin yoğun olarak görüldüğü ve Endüstri 2.0 olarak adlandırılan dönem yer almaktadır. Bu dönemde ise elektrik enerjisinin üretim teknolojilerinde kullanılmaya başlanması önemli rol oynamaktadır. 1970'lerin başlarından itibaren ise otomasyon teknolojilerinin geliştirilerek imalat sistemlerinde kullanılması Endüstri 3.0 olarak adlandırılan dönemin ortaya çıkışına neden olmaktadır. Bu dönemde bilgi teknolojilerinin üretimde yoğun etkisi olduğu görülmektedir. Endüstri 3.0 günümüze kadar devam eden ve halen birçok işletmenin içerisinde bulunduğu dönemdir. Günümüzde hemen hemen bütün işletmeler otomasyona ve bilgi iletişim teknolojilerine dayalı üretim yöntemleri üzerine kurulmuştur. Endüstri 4.0 ise çok yeni bir kavramdır ve henüz işletmeler Endüstri 4.0 dönemi içerisindedir denemez. Halen Endüstri 4.0 üzerine birçok soru mevcuttur ve dönemler arası geçiş aşamasının etkileri bulunmaktadır. Dördüncü sanayi devriminin bir kavram olarak ele alınmasında etkili olan en önemli teknolojiler ise nesnelerin interneti ve siber fiziksel sistemlerdir. Nesnelerin interneti ve siber fiziksel sistemler üretim teknolojilerini günümüzde şekillendiren ve ileriye taşıyacak olan en önemli kavramlardır. Ancak halen Endüstri 4.0'ın ne olduğu ve nelerin yapılması konusunda birçok soru mevcuttur.

Endüstri 4.0 için bir başlangıç noktası belirlenmek istenirse; 2011 yılında düzenlenen Hannover Fuarı Endüstri 4.0 için bir başlangıç noktası olarak kabul edilebilir. Buna karşılık, Almanya'nın bu yaklaşımları resmi sanayi politikası olarak belirlemesiyle Endüstri 4.0 fiilen başlamıştır.

Endüstri 4.0'ı en iyi anlayabilmek için gerçek hayatta olması beklenen uygulamalardan bir örnekle açıklama daha doğru olacaktır. Örneğin müşteri raftan bir ürünü aldığında ürün üzerinde bulunan mikroçipler raflarda konumlandırılmış terminallerle bilgiyi transfer ederek, raftaki ürün miktarının bir adet azaldığının bilgisini iletecek. Bu bilgi terminaller aracılı̆̆ıyla sistemde bulunan bütün aktörlere otomatik olarak akacak ve tüm tedarik, üretim ve lojistik faaliyetlerle ilgili tüm unsurlar bu bilgi karşısında yapmaları gerekeni otonom olarak yapmaya başlayacaklar. Daha da etkileyici olan nokta ise bu fonksiyonların insan faktörü olmaksızın gerçekleşecek olması, dolayısıyla insanların sistemi opere etmesine gerek kalmaksızın sistemin kendiliğinden işleyebilme kabiliyetine sahip olmasıdır (Görçün, 2016, s.144).

\section{LITERATÜR INCELEMESI}

Endüstri 4.0 ile birlikte "Akıllı Fabrikalar" gündeme gelmiştir. Akıllı fabrikaların mümkün olmasıyla birlikte sanal ve fiziksel imalat sistemleri küresel planda birbirleriyle esnek bir şekilde işbirliği yapmaya başlamaktadır. Böylece ürünün tamamen müşteriye özel hale getirebilmesi ve global olarak yeni operasyon modellerinin yaratılması mümkün olmaktadır.

Dördüncü bir sanayi devriminin varlı̆ıından bahsedebilmek için araştırmacılarda gerekli kanaatin oluşumunu etkileyen faktörler değişim göstermektedir. Günümüzde Endüstri 4.0 dönemi içerisinde olduğumuzu savunan araştırmacılar olduğu kadar halen Endüstri 3.0 içerisinde olduğumuzu savunan araştırmacılar da mevcuttur. Ancak Endüstri 4.0 dönemi içerisinde bulunulduğu kanaatine varmayı güçlendirecek üç önemli neden şunlardır (Schwab, 2016, s. 11):

Hız: Önceki sanayi devrimlerinin tam tersine bu devrim doğrusal değil üstel bir hıza gelişmektedir.

Genişlik ve derinlik: Bu devrim dijital devrimin üzerinde yükselmektedir ve ekonomide, iş dünyasında, toplumda ve bireysellikte benzeri görülmedik paradigma değişimlerine götüren çok çeşitli teknolojileri bir araya getirmektedir. İşleri yapmadaki “Ne?" ve "Nasıl?" sorularının yanında "Biz kimiz?" sorusu da değişim göstermektedir.

Sistem etkisi: Bu devrim ülkeler, şirketler, sektörler arasında ve içinde bir bütün olarak toplumda sistemlerin bütünsel dönüşümünü içermektedir.

Endüstriyel devrimlerin temel özelliklerine bakıldığında daha önceki dönemlerde gelişme ve yayılma hızının daha düşük olduğu görülmektedir. Diğer bir yandan endüstriyel devrimler dünyanın her yanında aynı anda ve aynı derecede etkiye sahip olmamaktadırlar. Yani farklı coğrafyalarda farklı gelişmişlik düzeylerinin olması da gayet doğaldır. Örneğin günümüzde halen 1,3 milyar kişinin elektrik erişimine sahip olmadığı bilinmektedir ve dünya nüfusunun \%17'si halen Endüstri 2.0 dönemini yaşamaktadır. Aynı durum Endüstri 3.0 için de geçerlidir. Dünya nüfusunun büyük bir kısmı internet erişimine sahip değildir. Ancak internetin yayılma hızı ile önceki teknolojilerin yayılma hızı arasında büyük bir fark bulunmaktadır. Örneğin iplik makinesinin Avrupa'nın dışında yayılması neredeyse 120 yıl almıştır. İnternetin günümüzdeki halini alması ve yaygınlaşması ise yaklaşık 15 yıl sürmüştür. Endüstri 4.0 teknolojilerinin yayılma hızının beklenenden daha da fazla olacağı buradan da tahmin edilebilmektedir (Schwab, 2016, s. 17).

Endüstri 4.0 insan ve nesne arasında etkileşimin en üst düzeyde sağlandığı, olabilecek en üst düzeyde katma değer yaratabilmek için veri akışının eşzamanlı, organize ve sistemli bir biçimde sağlanabildiği, makine ve ekipmanların otonom olarak faaliyet gösterdiği bir süreçtir (Görçün, 2016, s. 144).

Endüstri 4.0 sürecinin oldukça kapsamlı olmasından dolayı bu süreci ele alırken bileşenlerine ayırmak hem süreci araştıran hem de uygulayan açısından daha faydalı olmaktadır. Öncelikle farklı kaynaklardaki Endüstri 4.0 bileşenleri kısaca verilmiştir. 
Daha sonra araştırmacılar tarafından uygulamada kullanılmak üzere seçilen Endüstri 4.0 bileşenleri alt başlıklarda detaylı olarak açıklanmıştır.

TÜSiAD’a göre geleceğin sanayi üretimini şekillendirecek olan Sanayi 4.0 (Endüstri 4.0)'ı şekillendiren dokuz teknolojik ilerleme şunlardır (TÜSIAD, 2016, s. 25):

\section{Akıllı robotlar \\ 2. Simülasyon}

3. Yatay/dikey yazılım entegrasyonu

4. Nesnelerin interneti (donanıma entegre sensörler ağı)

5. Siber güvenlik

6. Bulut

7. Eklemeli üretim (örneğin 3D baskı)

8. Zenginleştirilmiş gerçeklik

9. Büyük veri ve analiz

Görçün'e göre Endüstri 4.0 süreci çok sayıda bileşene sahip olan ve bu bileşenlerin etkinlik düzeyinden büyük ölçüde etkilenen bir süreçtir. Bu bileşenler şunlardır (Görçün, 2016, s. 146):

1. Nesnelerin interneti

2. Akıllı fabrikalar

3. Siber fiziksel sistemler

4. Büyük veri

5. Otonom robotlar

6. Simülasyon

7. Entegre sistemler

8. Bulut bilişim sistemleri

9. Artırılmış gerçeklik

10. 3D yazıcilar

Hermann, Pentek ve Otto'nun çalışmasında yer alan Endüstri 4.0 bileşenleri ise şunlardır (Hermann, Pentek ve Otto, 2016):

1. Siber fiziksel sistemler

2. Nesnelerin interneti

3. Akıllı fabrikalar

4. Hizmetlerin interneti

5. Akıllı ürün

6. M2M sistemleri (Makine-makine sistemleri)

7. Büyük veri

8. Bulut

Diğer araştırmacıların çalışmalarında yer verdikleri Endüstri 4.0 bileşenleri incelendikten sonra bu araştırmada kullanılan bileşenler listesi Tablo 1'de yer almaktadır. 
Tablo 1: Endüstri 4.0 Bileşenleri

\begin{tabular}{cl}
\hline Bileşen No & Bileşen Adı \\
\hline 1 & Akıllı robotlar \\
2 & Simülasyon (Benzetim) \\
3 & Yatay/dikey yazılım entegrasyonu \\
4 & Nesnelerin interneti \\
5 & Yapay zekâ \\
6 & Siber güvenlik \\
7 & Bulut \\
8 & Eklemeli üretim \\
9 & Artırılmış gerçeklik \\
10 & Büyük veri analizi \\
11 & Akıllı fabrikalar \\
12 & Siber fiziksel sistemler \\
\hline
\end{tabular}

Endüstri 4.0'ın çok yeni bir kavram olmasından dolayı henüz kapsamı ve içeriğine dair yeterli bir bilgi birikimi oluşmamış durumdadır. Aynı nedenden ötürü kesin bir tanımı da yapılamamıştır. Belirtilen nedenlerden dolayı Endüstri 4.0'ı ele alırken bütünü parçalarına ayıran bir yaklaşım benimsemek daha doğru olacaktır. Belirtilen bileşenler ise Endüstri 4.0'ı meydana getiren parçaları ifade etmede kullanılabilmektedir. Teknolojik ilerlemelerden yola çıkılarak belirlenen 12 bileşen doğrultusunda işletmelerin Endüstri 4.0 kapsamında değerlendirmesi yapılmaktadır.

\section{VERI VE YÖNTEM}

İşletmelerin Endüstri 4.0 bağlamında değerlendirilmesine yönelik veri toplanması amacıyla bir anket hazırlanmıştır. Bu anket 4 ana bölüm altında toplam 51 sorudan oluşmaktadır. Anketin ana bölümlerinin ölçümlediği alanlar sırasıyla işletmelerin demografik bilgileri, işletmelerin Endüstri 4.0 farkındalıkları, işletmelerin Endüstri 4.0 uygulamalarını (bileşenlerini) bünyelerinde uygulayıp uygulamadıkları ve işletmelerin Endüstri 4.0'a bakış açılarıdır.

Anketler Eskişehir ili Organize Sanayi Bölgesi'nde imalat sektöründe yer alan KOBi'lere uygulanmıştır. Eskişehir OSB Bölge Müdürlüğü ile Mart 2017 içerisinde yapılan görüşme sonucunda bölgede imalat sektöründe yer alan toplam KOBi sayısının 138 olduğu bilgisi alınmıştır. İmalat sektörü dışında diğer alanlarda faaliyet gösteren KOBi'ler çalışma kapsamında değerlendirilmemiştir. Bunun başlıca nedeni Endüstri 4.0 teknolojilerinin uygulanması için oluşan zeminin imalat sektöründe daha geniş ve sağlam olmasıdır. Hizmet ya da tarım sektörlerine yönelik faaliyet alanı olan KOBi'lerde ise Endüstri 4.0 teknolojilerinin uygulama alanının yeterince olgunlaşmadığı ve bu işletmelerin Endüstri 4.0 kapsamında değerlendirilmesi için erken olduğu düşünülmektedir.

Yapılan anketler işletmelere mail yoluyla iletilmiştir ve işletmelerdeki sorumlu kişilere anketin doldurulmasına gerekli noktalarda telefon yoluyla ya da yüzyüze bilgi verilmiştir. Çalışma kapsamında toplam 104 geçerli anket elde edilmiştir. Araştırmanın evrenini Eskişehir ili OSB'de faaliyet gösteren ve imalat sektöründe yer alan KOBi'ler oluşturmaktadır. Ana kütlede yer alan 138 işletme için yeterli örneklem büyüklüğü ise \%95 güven düzeyi ve \%95 güven aralığı için 102 işletme olup, 104 geçerli anketin yer aldığı örneklem evreni temsil edebilecek büyüklüktedir. Çalışmada temel olarak tanımlayıcı istatistiksel yöntem kullanılmaktadır ve bu doğrultuda mevcut durum ortaya konularak üzerinde tartışımaktadır.

Ankette yer alan demografik bilgi alanında işletmelerin hangi alanda faaliyet gösterdikleri, işletmede çalışan kişi sayısı, işletmede teknoloji alanında kalifiye olan çalışan sayısı, işletmenin yıllık satış hasılatı aralığı, işletmenin faaliyet gösterdiği süre değişkenlerine yönelik sorular yer almaktadır. Bu bölümde yer alan faaliyet alanı değişkeni isimsel ölçeğe, faaliyet süresi oranlı ölçeğe, çalışan sayıları ile satış hasılatı ise sıralı ölçeğe sahiptir.

Ankette yer alan Endüstri 4.0 farkındalığının ölçüldüğü bölümde yer alan sorular ise Tablo 2'de yer almaktadır. Farkındalığa yönelik değişkenler beşli Likert tipi ölçeğe göre yapılandırılmıştır. 1 değeri önermeye kesinlikle katılmıyorum, 5 değeri tamamen katılıyorum ifadesini belirtmektedir.

\section{Tablo 2: Endüstri 4.0 Farkındalık Soruları}

1 Endüstri 4.0 teknolojileri konusunda bilgi sahibiyim.

2 İşletmemiz Endüstri 4.0 ile ilgilenmektedir.

3 İşletmemiz Endüstri 4.0 konusunda yeterli bilgi sahibidir.

4 Üst düzey yönetim Endüstri 4.0'ın farkındadır.

5 Endüstri 4.0 uygulamaları işletmemizin içinde bulunduğu sektördeki genel görünümü değiştirecektir.

6 Türkiye'nin uluslararası alanda daha fazla paya sahip olması için daha fazla katma değere ihtiyacı olacaktır. 
7 Endüstri 4.0 uygulamaları uluslararası alanda daha fazla pay kazanmayı mümkün kılacaktır.

Endüstri 4.0 uygulamalarına yapılacak olan yatırımlar uzun vadede uluslararası alandaki payın büyümesini

8 sağlayacaktır.

9 Endüstri 4.0 uygulamaları istihdamı arttıracaktır.

10 Endüstri 4.0 uygulamalarının hayata geçirilebilmesi için işletmelerin kendi başlarına çaba göstermeleri yeterlidir.

11 Endüstri 4.0 uygulamaları üretim maliyetlerini azaltacak ve işletme verimliliğini arttıracaktır.

Ankette yer alan üçüncü bölümde ise işletmelerin mevcut durumda kullandıkları Endüstri 4.0 teknolojileri (bileşenleri) sorulmaktadır. Bu bölümde yer alan bileşenlere yönelik sorularda ilgili bileşenin işletmede kullanıp kullanılmadığı sorusuna evet ya da hayır cevabı verilmektedir ve ilgili değişkenlerin ölçüm düzeyi isimseldir. İlgili Endüstri 4.0 bileşenleri literatür bölümü sonunda Tablo 1'de yer alan 12 bileşendir.

Ankette yer alan son bölümde ise işletmelerin Endüstri 4.0'a bakış açıları değerlendirilmektedir. Bu doğrultuda isimsel ölçüm düzeyine sahip değişken verilerinin toplandığı sorular Tablo 3'te yer almaktadır.

\section{Tablo 3: Endüstri 4.0’a Bakış Açısı Soruları}

\begin{tabular}{|c|c|c|}
\hline & Endüstri 4.0 Bakış Açısı Sorusu & Değişken Kategorileri \\
\hline 1 & $\begin{array}{l}\text { İşletmeniz orta ya da uzun vadede Endüstri } 4.0 \text { teknolojilerine } \\
\text { geçiş yapmayı planlamakta mıdır? } \\
\text { İşletmeniz gelişen Endüstri } 4.0 \text { teknolojilerini göz önünde }\end{array}$ & Evet, Hayır \\
\hline 2 & $\begin{array}{l}\text { bulundurarak nitelikli insan kaynağı bulma konusunda insan } \\
\text { kaynağı programları gelistirmekte midir? }\end{array}$ & Evet, Hayır \\
\hline 3 & $\begin{array}{l}\text { Size göre Endüstri } 4.0 \text { uygulamalarının en zor yanı } \\
\text { aşağıdakilerden hangisidir? }\end{array}$ & $\begin{array}{l}\text { Yatırım maliyeti, Nitelikli işgücü temini, Üretimde } \\
\text { sisteminde değişim, Üretim kontrol, Kalite kontrol, } \\
\text { Bilgi eksikliği, Eğitim, danışmanlık vb. destek eksikliği, } \\
\text { Finansal destek eksikliği }\end{array}$ \\
\hline 4 & $\begin{array}{l}\text { Aşağıda yer alan unsurlar üretimde işletmenizi ne kadar } \\
\text { zorlamaktadır? }\end{array}$ & $\begin{array}{l}\text { Üretim hızı, Üretim süreci, Üretim kalitesi, İşçilik, } \\
\text { Malzeme, Maliyet, Hazırlık süresi, Bakım, Zamanında } \\
\text { teslim, Rekabet }\end{array}$ \\
\hline 5 & $\begin{array}{l}\text { Sizce Endüstri } 4.0 \text { aşağıdaki konulardan hangisine en çok katkı } \\
\text { sağlayacaktır? }\end{array}$ & $\begin{array}{l}\text { Verimlilik, Ciro artışı, İstihdam, Yatırım, İş güvenliği, } \\
\text { Çalışma koşulları, Kişiye özel ürün, Üretim hattındaki } \\
\text { ürün çeşitliliği, Çevreyi koruma, İnovasyon, Rekabet, } \\
\text { Müşteri memnuniyeti, Maliyet, Kaynak etkinliği, } \\
\text { İşletme içi eğitim, Üretime dönük etkin veri kullanımı }\end{array}$ \\
\hline
\end{tabular}

\section{BULGULAR VE TARTIŞMA}

Çalışmada yer alan işletmelerin \%13,5'inde 1-9 kişi, \%29,8'inde 10-49 kişi, \%56,7'sinde ise 50-249 kişi çalışmaktadır. Bilişim teknolojileri alanında kalifiye çalışan sayılarının dağılımı ise işletmelerin \%26,9'unda hiç bulunmuyor, \%55,8'inde 1-5 kişi, \%3,8'inde 6-10 kişi, \%7,7'sinde 10-14 kişi, \%3,8'inde 15-9 kişi, \%1,9'unda 20 kişi ve üzeri şeklindedir.

İşletmelerin yıllık satış hasılatı dağılımına bakıldığında \%13,5'inin 1 milyon TL'den az, \%26,9'unun 1 ile 8 milyon TL arasında, \%56,9'unun ise 8 ile 40 milyon TL arasında olduğu görülmektedir. 250 kişiden fazla çalışanı olan ve 40 milyon TL'den fazla yıllık satış hasılatı olan işletmeler KOBİ tanımı içerisinde yer almadığından dolayı araştırmada yer almamaktadır.

Çalışmada yer alan işletmelerin faaliyet alanı dağılımı ise alfabetik sıraya göre ambalaj \%3,8, beyaz eşya \%9,6, diğer \%7,7, elektronik ve bilişim \%9,6, gıda-içecek \%1,9, kimyasallar \%5,8, maden $\% 1,9$, makine sistemleri $\% 13,5$, metal imalatı \%17,3, mobilya \%1,9, otomotiv \%8,7, seramik \%8,7, tekstil \%4,8, yapı malzemeleri \%3,8, yedek parça \%1 olacak şekildedir. İşletmelerin faaliyet alanlarının metal imalatı, makine sistemleri, beyaz eşya, elektronik ve bilişim alanlarında yoğunlaştığı görülmektedir. Bu durum Endüstri 4.0'a yönelik bir çalışmada yer alma doğrultusunda hevesli olan faaliyet alanlarını belirten bir bulgu olarak da karşımıza çıkmaktadır. Ayrıca işletmelerin faaliyet gösterdikleri süre yıl cinsinden 1 ile 122 arasında değer almaktadır ve ortalaması 25,23 yıldır. Işletmelerin Endüstri 4.0'ın ne kadar farkında olduklarına yönelik çıktılar Tablo 4'te yer almaktadır.

Tablo 4: İşletmelerin Endüstri 4.0 Farkındalıkları

\begin{tabular}{llc}
\hline & Farkındalık Önermesi & Farkındalık Düzeyi (5’li Likert Tipi Ölçek Üzerinden) \\
\hline 1 & Endüstri 4.0 teknolojileri konusunda bilgi sahibiyim. & 3,16 \\
2 & İşletmemiz Endüstri 4.0 ile ilgilenmektedir. & 3,41 \\
3 & İşletmemiz Endüstri 4.0 konusunda yeterli bilgi sahibidir. & 2,43 \\
4 & Üst düzey yönetim Endüstri 4.0'ın farkındadır. & 3,23
\end{tabular}


5 Endüstri 4.0 uygulamaları işletmemizin içinde bulunduğu sektördeki genel görünümü değiştirecektir.

Türkiye'nin uluslararası alanda daha fazla paya sahip olması için daha fazla katma değere ihtiyacı olacaktır. Endüstri 4.0 uygulamaları uluslararası alanda daha fazla pay kazanmayı mümkün kılacaktır.

8 Endüstri 4.0 uygulamalarına yapılacak olan yatırımlar uzun vadede uluslararası alandaki payın büyümesini sağlayacaktır.

9 Endüstri 4.0 uygulamaları istihdamı arttıracaktır.

Endüstri 4.0 uygulamalarının hayata geçirilebilmesi için işletmelerin kendi başlarına çaba göstermeleri yeterlidir. Endüstri 4.0 uygulamaları üretim maliyetlerini azaltacak ve 11 işletme verimliliğini arttıracaktır.
3,95

2,64

2,20

4,06

Farkındalığın ölçümüne yönelik değişkenlerde en yüksek standart sapma 1,293 ile "Endüstri 4.0 teknolojileri konusunda bilgi sahibiyim." sorusuna yönelik olan bilgi düzeyi değişkenidir. Diğer değişkenlerin standart sapmaları 1 civarında $(+0,3,-0,3)$ yer almakta olup, en düşük standart sapma ise 0,709 "Türkiye'nin uluslararası alanda daha fazla paya sahip olması için daha fazla katma değere ihtiyacı olacaktır." sorusuna yönelik olan katma değer değişkenine aittir. İşletmelerin Endüstri 4.0 farkındalıkları incelendiğinde, Endüstri 4.0'ın verimlilik ve katma değeri arttıracağı ancak diğer bir yandan ise istihdamı olumsuz yönde etkileyeceğinin bilincinde oldukları görülmektedir. Uzun vadede yatırımların gerekliliği konusunda farkındalık göze çarpmaktadır. Diğer bir yandan ise anket katılımcıları kendilerinin bireysel olarak Endüstri 4.0 hakkında bilgi sahibi olduklarını ancak işletme düzeyinde ve üst düzey yönetim kademelerinde bu konuda yeterli bilgi sahibi olunmadığını belirtmektedirler. Endüstri 4.0'ın sektörün genel görünümü değiştireceği yönündeki farkındalık düzeyi de genel olarak gelişmiş durumdadır. Son olarak işletmeler Endüstri 4.0 teknolojilerini kendi çabalarıyla hayata geçiremeyeceklerini ve bunun için finansal destek, bilgi paylaşımı, stratejik işbirliği gibi ortak platformlara ihtiyaç duyduklarını belirtmektedirler.

İşletmelerin Endüstri 4.0 teknolojilerini kullanıp kullanmadıklarına yönelik değişkenlere ait çıktılar Tablo 5'te yer almaktadır. illgili sorularda işletmelerin belirtilen teknolojiyi kullanıp kullanmadığı sorulmuştur. Tabloda yer alan yüzdeler ise ilgili teknolojiyi/bileşeni kullanan işletmelerin oranlarıdır.

Tablo 5: İşletmelerin Endüstri 4.0 Bileşenlerini Kullanım Oranları

\begin{tabular}{clc}
\hline Bileşen No & Bileşen Adı & Kullanım Oranı (\%) \\
\hline 1 & Akıllı robotlar & 25 \\
2 & Simülasyon (Benzetim) & 44,2 \\
3 & Yatay/dikey yazılım entegrasyonu & 45,5 \\
4 & Nesnelerin interneti & 35,6 \\
5 & Yapay zekâ & 9,6 \\
6 & Siber güvenlik & 37,5 \\
7 & Bulut & 38,5 \\
8 & Eklemeli üretim & 18,3 \\
9 & Artırılmış gerçeklik & 7,7 \\
10 & Büyük veri analizi & 18,3 \\
11 & Akıllı fabrikalar & 19,2 \\
12 & Siber fiziksel sistemler & 7,7 \\
\hline
\end{tabular}

İşletmelerin Tablo 5'te yer alan teknolojileri kullanım oranları incelendiğinde en yüksek oranda yatay/dikey yazııım entegrasyonunun sağlandığı görülmektedir. İşletmelerin kullandıkları ERP yazııımları bu kapsamda değerlendirilmiştir. Genel olarak simülasyon uygulamalarının, siber güvenliğin, bulut sistemlerinin öneminin farkına varılmış ve gerekli geliştirmelerin hayata geçirilmeye başlandığı söylenebilir. Ancak bu üç teknolojinin geliştirildiği tarihler ve giderek artan önem düzeyleri göz önünde bulundurulduğunda tabloda görünen oranların beklenenin çok üzerinde olduğu söylenemez. Endüstri 4.0'ın temel olarak dayandığı iki önemli bileşen nesnelerin interneti ve siber fiziksel sistemler olarak kabul edilmektedir. Ayrıca ilgili sistemlerin ve teknolojilerin de birden fazlasının yapay zekâ desteği ile kullanımı gerçek anlamda bir çağ atlama olarak kabul edilmektedir. Hali hazırdaki duruma bakıldığında işletmeler arasında belirtilen teknoloji bütünlüğünü yakalamış olan işletmelerin oranı \%2 civarındadır. Diğer bir yandan nesnelerin interneti bileşeni için işletmeler üretim sahasında bulunan sensör ağlarını göz önünde bulundurarak cevap vermişlerdir. Üretim sonrasında ürün takibine yönelik nesnelerin interneti ağını göz önünde bulundurmamışlardır. Bu durumda \%2 olarak belirtilen işletme grubunun da gerçek anlamda Endüstri 4.0’a geçiş yaptığı tartışılabilir bir konu olarak karşımıza çıkmaktadır. Ancak mevcut durumda sadece üretim sahası göz önünde 
bulundurulsa da bu oran Endüstri 4.0'a geçişe yönelik kıvılcımın ateşlendiğini ve Eskişehir'de bunun farkında olan işletmelerin yer aldığını göstermektedir. \%2'lik dilimde belirtilen işletmelerin faaliyet alanı metal imalatıdır.

Akıllı robot teknolojisini kullanan işletmelerin oranı ise \%25 olup, bu oran içerisinde en fazla paya sahip olan sektörler metal imalatı ve otomotivdir. Nesnelerin interneti konusunda harekete geçmiş olan işletmelerin oranı ise \%35,6 olup bu işletmelerin arasında en fazla paya sahip olan elektronik ve bilişim alanındakilerdir. Elektronik ve bilişim alanını takip eden işletmeler ise metal imalatı alanında faaliyet göstermektedir. Metal imalatı alanında faaliyet gösteren işletmeler genel olarak Endüstri 4.0'a yatkın olarak görülmektedir. Eskişehir ilindeki KOBíler arasındaki oranı da göz önünde bulundurulduğunda $(\% 17,3)$ şehrin ekonomisindeki rolleri büyüktür ve daha fazla katkı sağlama potansiyelleri yüksektir.

kıllı fabrikalar ile siber fiziksel sistemler teknolojilerindeki oranlar her ne kadar az da olsa beklenenden yüksek durumdadırlar. Çünkü bu teknolojiler yoğun bilgi birikimi ve büyük yatırımlar gerektirmektedirler. Henüz yeni olan bu teknolojiler için bu kadar kısa sürede bu bilgi birikiminin elde edilmesine yönelik kapsamlı çalışmalar/ortaklıklar ya da büyük yatırımların yapılması mümkün gözükmemektedir. Bu nedenle işletmelerin ilgili teknolojiler konusunda yeterli bilgiye sahip olmadığı düşünülebilir. Bu durumda Endüstri 4.0 teknolojileri konusunda eğitim faaliyetlerinin işletmelere yönelik planlanmasının gerekliliği görülmektedir.

Eklemeli üretim teknolojisinin işletmelerdeki kullanım oranı \%18,3 olup bu oran yeterli seviyededir. Eklemeli üretim teknolojisine örnek olarak 3D yazıcılar gösterilebilir. Ürünün talaş kaldırarak ya da kalıba dökülerek üretilmesi yerine katmanların üst üste eklenerek üretilmesini ifade etmektedir. Bilindiği üzere 3D yazıcı teknolojisi oldukça yeni bir teknoloji olmasına rağmen birçok alanda kısa sürede kullanım alanı bulmuştur. Özellikle yeni tasarımların prototiplerinin hemen hayata geçirilmesi, kişiye ya da konuya özel ürünlerin seri üretime gerek duyulmadan üretilebilmesi ve her geçen gün daha düşük maliyetli hale gelmesi gibi nedenlerden dolayı işletmeler açısından rekabetçi avantaj sağlayan üretim yöntemlerinden biri haline gelmektedir.

Son bölümde yer alan Endüstri 4.0'a bakış açısına yönelik değişkenlerin çıktılarına bakıldı̆̆ında ise işletmelerin \%63,5'inin orta ya da uzun vadede Endüstri 4.0 teknolojilerine geçiş yapmayı planladıklarını göstermektedir. Ancak diğer bir yandan işletmeler arasında Endüstri 4.0 teknolojilerini göz önünde bulundurarak nitelikli insan kaynağı yetiştirme konusunda program geliştirenlerin oranı \%26,9'dur. Bilişim teknolojileri alanında uzman insan kaynağı yetiştirme konusunda işletmelerin yeterli çabasının olmadığı görülmektedir. Diğer bir yandan nitelikli insan kaynağı yetiştirme konusunda yükseköğretim kurumlarının sorumluluk almasını düşündükleri de söylenebilir. Her iki durumda da orta ya da uzun vadede bilişim teknolojileri alanında insan kaynağı ihtiyacının artacağı görülmektedir. İşletmelerin büyük bölümü Endüstri 4.0 uygulamalarının en zor yanının yatırım maliyeti olduğunu düşünmektedir $(\% 47,1)$. Bu oranı \%18,3 ile bilgi eksikliği ve \%13,5 ile üretim sistemindeki değişimin zorluğu konuları takip etmektedir.

İşletmeleri mevcut durumda üretimde en çok zorlayan unsur maliyettir. İkinci ve üçüncü sırada ise işçilik ve rekabet gelmektedir. Son olarak ise işletmelerin Endüstri 4.0'ın en çok katkı sağlayacağını düşündüğü konu verimliliktir. Verimliliği sırasıyla maliyetin azalması ve inovasyon konuları takip etmektedir.

\section{SONUÇ}

Eskişehir ilinde imalat sektöründe yer alan KOBi'lere yönelik olan çalışmada ilk bakışta Endüstri 4.0 konusunda farkındalığın oluşmuş olduğu görülmektedir. KOBi'lerin ülke ekonomisi içerisindeki payı dikkate alındığında bu durumdan ekonominin orta ve uzun vadede olumlu yönde etkileyeceği çıkarılabilir. Genel olarak Endüstri 4.0 konusunda farkındalık yüksek düzeyde olsa da Endüstri 4.0 teknolojileri kullanım oranları beklenenden düşük seviyededir. Bileşenler arasında yer alan teknolojilerin çoğu her ne kadar çok yeni olsa da daha eski olan teknolojilerde dahi düşük kullanım oranları görülmektedir. Bunların başında büyük veri analizi gelmektedir. Simülasyon ve yazılım entegrasyonunun da daha fazla kullanım oranlarında olması gereklidir.

Endüstri 4.0 teknolojileri konusunda işletmelerin üst düzey yönetimlerinin yeterli bilgiye sahip olmadıkları görülmektedir. İşletme yöneticilerinin ve diğer düzeylerindeki sorumluların bilgilendirilmesi yönünde eğitimlerin düzenlenmesi gereklidir. Bu doğrultuda Sanayi Odalarına, Ticaret Odalarına, KOSGEB'e ve üniversitelere sorumluluk düşmektedir.

İşletmeler her ne kadar Endüstri 4.0'ın büyük ölçüde olumlu katkılar sağlayacağını düşünseler de geçiş sürecinin zor olacağını düşünmektedirler. Özellikle yatırım maliyeti unsuru işletmeler açısından zorluk teşkil etmektedir. Bu doğrultuda yapılabilecek adımların başına Bilimi Sanayi ve Teknoloji Bakanlığı tarafından geliştirilecek stratejik plan dahilinde fonlama sistemi gelmektedir. Ayrıca işletmeler bu doğrultuda Avrupa Birliği Ufuk 2020 kapsamında yeni teknolojiler geliştirmeye yönelik projeler de geliştirebilirler. Proje geliştirme ve Endüstri 4.0 teknolojileri konusunda bilgi eksikliğinin ise giderilmesi doğrultusunda üniversite destekli platformların oluşturulması faydalı olacaktır.

Endüstri 4.0 konusunda işletmeler her ne kadar gelişmiş farkındalığa sahip olsalar da uzun vadede nitelikli insan kaynağına yönelik herhangi bir aksiyon almamış durumdadırlar. Endüstri 4.0 her ne kadar genel olarak istihdamı azaltacak olsa da 
nitelikli insan kaynağı ihtiyacı önemli ölçüde artacaktır. Bu konuda önlem almamış olan işletmeler uzun vadede darboğaza gireceklerdir.

Çalışmada Eskişehir ilinde KOBi'lerin Endüstri 4.0 bağlamında mevcut durumu ortaya konarak, belirlenen bileşenler çerçevesinde değerlendirilmiştir. Ayrıca genel Endüstri 4.0 farkındalık düzeyi ve Endüstri 4.0'a bakış açısı da yorumlanmıştır. Yapılan çalışma neticesinde büyümekte olan Eskişehir sanayisinin yeni teknolojiler açısından potansiyeli olduğu ve bu potansiyeli kullanmaya yönelik harekete geçtiği görülmektedir. Ancak işletmelerin Endüstri 4.0'a giden bu zorlu yolda tek başlarına çabaları yeterli olmayacaktır. Bu doğrultuda kamu kesimi ve düzenleyici otoritelerin de desteğine ihtiyaç duyulmaktadır

Endüstri 4.0’a yönelik mevcut durumun ortaya konulmasından sonra ileride yapılacak olan çalışmalar için işletme, sektör ve bölge düzeyinde stratejilerin belirlenmesi konusunda SWOT analizlerinin yapılması önerilmektedir. Ayrıca bu çalışmada yer alan bileşenler diğer şehirlerdeki КОВi'lerin durumlarının kıyaslanması açısından da faydalı olacaktır. Şehirler ya da bölgeler arası kıyaslamalar tüm ülke ekonomisinde dengeli bir büyüme sağlanması açısından yarar sağlayacaktır.

\section{KAYNAKLAR}

Banger, G. (2016). Endüstri 4.0 ve Akıllı İşletme. Ankara: Dorlion.

Ege, B. (2014). 4. Endüstri Devrimi Kapıda mı? TÜBiTAK Bilim ve Teknik Dergisi, p. 26-29.

Görçün, Ö. F. (2016). Endüstri 4.0: Dördüncü Endüstri Devrimi. İstanbul: Beta.

Hermann, M., Pentek, T., \& Otto, B. (2016). Design principles for industrie 4.0 scenarios. 49th Hawaii International Conference, p. 39283937.

Schwab, K. (2016). Dördüncü Sanayi Devrimi. (Z. Dicleli, Çev.) İstanbul: Pasifik.

Türk, A. (2016). Endüstri 4.0: "Akıllı" Yeni Dünya Dördüncü Sanayi Devrimi. EkolQ Dergisi. İstanbul. http://ekoiq.com/wpcontent/uploads/2014/12/ekoiq-ek-d.pdf

TÜSIAD. (2016). Türkiye'nin Küresel Rekabetçiliği İçin Bir Gereklilik Olarak Sanayi 4.0. İstanbul: TÜSIAD. 